\title{
UJI VALIDITAS KONSTRUK ALAT UKUR PERSEPSI HUBUNGAN ORANGTUA-ANAK TERHADAP PERILAKU SEKSUAL PADA MAHASISWA
}

\author{
Eva Ramdhani Fujitari \\ evaramdhni@gmail.com \\ Anggota HIMPSI Jakarta
}

\author{
Abdul Rahman Shaleh \\ Abd.rahman.Shaleh@uinjkt.ac.id \\ Fakultas Psikologi Uin Syarif Hidayatullah \\ Jakarta
}

\begin{abstract}
This research aims to measure the construct validity of the parent-child relationship scale developed by theory Miller, Benson and Galbraith (2001). The scale made by researcher consists of 24 items with three dimensions of parent-child relationship, that is support, open communication, and control of the parents will affect the child in conducting sexual behavior. This research just see the parentchild relationship from the side of the child (college student) so the researcher adds perception theory to clarify the purpose of the research, that is to see the college student perception about the relationship with the parents and the effect on sexual behavior. The sample this research is 200 respondents of male and female college student. The research data is analyzed using confirmatory factor analysis (CFA) technique with lisrel 16.0 program.
\end{abstract}

Keywords : construct validity, parent-child relationship, parent-child relationship scale

\begin{abstract}
Abstrak
Tujuan dari penelitian ini yaitu untuk menguji validitas konstruk skala hubungan orangtua-anak yang dikembangkan berdasarkan teori Miller, Benson dan Galbraith (2001). Alat ukur yang dibuat oleh peneliti ini terdiri dari 24 item dengan tiga dimensi hubungan orangtua-anak berupa dukungan, komunikasi terbuka, dan kontrol dari orang tua akan mempengaruhi anak dalam melakukan perilaku seksual. Pada penelitian kali ini, peneliti hanya melihat hubungan orangtua-anak dari sisi anak (mahasiswa) sehingga peneliti menambahkan teori persepsi untuk memperjelas tujuan dari penelitian yaitu melihat persepsi mahasiswa mengenai hubungan dirinya dengan orangtua serta pengaruhnya terhadap perilaku seksual. Sampel yang digunakan berjumlah 200 responden yang terdiri dari mahasiswa laki-laki dan perempuan. Dianalisis menggunakan metode Confirmatory Factor Analysis (CFA) dengan bantuan program Lisrel 16.0.
\end{abstract}

Kata kunci: validitas konstruk, hubungan orangtua-anak, skala hubungan orangtua-anak, CFA. 


\section{PENDAHULUAN}

Hubungan yang terjalin dengan baik antara orangtua-anak akan melindungi anak dari perilaku seksual sejak dini (Sidze \& Defo, 2013). Hal tersebut dapat terjadi karena hubungan orangtua - anak memiliki keterkaitan dengan perilaku seksual seperti keputusan untuk menunda atau mengurangi perilaku seksual (Scony, Deptula, \& Henry, 2010; Miller, 2002).

Hubungan antara orangtua-anak bermanfaat untuk membantu individu menghindari perilaku seksual karena akan memberikan efek perlindungan pada hubungan yang dijalin antara anak laki- laki dan perempuan (Scony, Deptula, \& Henry, 2010). Dengan demikian, kemampuan anak untuk menjalani hubungan awal yang lebih positif dengan menghindari perilaku seksual akan meningkat (Parkes, Henderson, Wight, \& Nixon, 2011). Secara teoritis hubungan antara orangtua-anak adalah dukungan orangtua, kontrol orangtua, dan komunikasi terbuka orangtua-anak akan memiliki efek terhadap perilaku yang dimunculkan individu (Miller, Benson \& Galbraith, 2001).

Dukungan orangtua-anak memainkan peran penting dalam membina perilaku yang tepat dan dapat diterima (Markham, et al., 2010). Sedangkan, anak yang tidak merasa memiliki dukungan dari orangtuanya akan lebih dekat dengan teman-temannya yang mungkin melakukan tindakan yang menyimpang (Miller, Benson, \& Galbraith, 2001).

Individu yang mendapatkan pengawasan atau kontrol dari orangtua akan memiliki peluang yang kecil untuk terlibat perilaku seksual. Meskipun demikian, beberapa penelitian menyebutkan bahwa kontrol yang berlebihan dari orangtua justru akan membuat anak melakukan perilaku seksual (Crockett, Raffaelli, \& Moilanen, 2003). Komunikasi tertutup menghambat individu untuk menginternalisasi pesan yang di sampaikan oleh orang tua. Sebaliknya, komunikasi terbuka mendorong individu untuk menginternalisasi nilai-nilai dan norma-norma yang tertanam dalam pesan orang tua (Whitaker \& Miller, 2000) dan berkontribusi terhadap penurunan kemungkinan perilaku seksual hanya untuk anak perempuan, namun tidak ditemukan pada anak laki-laki (Henrich, Brookmeyer, Shrier, \& Shahar, 2006).

\section{Dimensi hubungan orangtua-anak}

Hubungan orang tua-anak yang didefinisikan oleh Miller, Benson, dan Galbraith (2001) terdiri dari:

\section{Dukungan orangtua}

Rendahnya dukungan dari orang tua kepada anak berhubungan dengan kecenderungan yang lebih besar pada aktivitas seksual. Hal ini dikarenakan anak yang tidak memiliki kedekatan dengan orangtuanya akan lebih dekat dengan teman-temannya yang memiliki kecenderungan untuk melakukan tindakan yang menyimpang.

Whitbeck et al (1992) menyebutkan bahwa akibat yang ditimbulkan dari rendahnya dukungan orangtua berbeda untuk anak laki-laki dan anak perempuan. Bagi anak perempuan rendahnya kedekatan yang terjalin antara dirinya dengan orangtuanya akan menyebabkan depresi yang akhirnya akan 
membuatnya melakukan perilaku seksual, sedangkan untuk anak laki-laki akibat yang muncul karena kurangnya kedekatan yang yang terjalin dengan orangtuanya akan cenderung mengalihkannya kepada minuman beralkohol (dalam Crockett, Raffaelli, \& Moilanen, 2003).

\section{Kontrol orangtua}

Individu yang mendapatkan pengawasan orangtua akan memiliki peluang yang ekcil untuk terlibat perilaku seksual. Namun, beberapa penelitian menyebutkan bahwa kontrol yang berlebihan dari orangtua akan membuat anak melakukan perilaku seksual (Crockett, Raffaelli, \& Moilanen, 2003).

3. Komunikasi terbuka antara orang tua-anak

Komunikasi terbuka antara orangtua dengan anak, serta fokus yang jelas pada topik seksual, kualitas hubungan orangtua- anak, dan nilai yang ditanamkan orangtua tentang aktivitas seksual kepada anak akan mempengaruhi perilaku anak terhadap hal yang berhubungan dengan seksualitas (Crockett, Raffaelli, \& Moilanen, 2003).

\section{METODE PENELITIAN}

\section{Populasi, sampel dan teknik pengambilan sampel}

Pada penelitian ini populasi yang digunakan adalah mahasiswa UIN Syarif Hidayatullah Jakarta. Teknik pengambilan sampel menggunakan teknik nonprobability sampling. Terdapat beberapa teknik dalam non-probability sampling, teknik yang digunakan pada penelitian ini adalah purposive sampling.

Sampel yang digunakan berjumlah 200 responden yang terdiri dari mahasiswa laki-laki dan perempuan. Jumlah sampel dalam penelitian ini berdasarkan pada rumus yang dibuat oleh Roscoe (Sugiono, 2011) yaitu 10 kali jumlah variabel penelitian. dengan demikian, hasil yang diperoleh dalam penelitian akan menunjukkan perilaku seksual mahasiswa sesuai dengan apa yang terjadi di dalam populasi yang digunakan.

\section{Instrumen penelitian}

Dalam skala Hubungan orangtua-anak, pada penelitian ini mengacu pada teori yang diungkapkan oleh Miller, Benson, dan Galbraith (2001) yang mendefinisikan Hubungan orangtua-anak berupa dukungan, komunikasi terbuka, dan kontrol dari orang tua akan mempengaruhi anak dalam melakukan perilaku seksual.

Alat ukur yang digunakan merupakan alat ukur yang dibuat sendiri oleh peneliti dengan mengembangkan teori Hubungan orangtua-anak yang diungkapkan oleh Miller, Benson, dan Galbraith (2001). Terdiri dari 24 item pernyataan dengan bentuk skala likert dimulai dari STS (sangat tidak sesuai), TS (tidak sesuai), s (sesuai), SS (sangat sesuai). Pada tabel 1.1 merupakan blue print skala Hubungan orangtua-anak yang terdiri dari 24 item. 
Tabel 1.1

Blue Print skala Hubungan orangtua-anak

\begin{tabular}{|c|c|c|c|c|}
\hline Aspek & Indikator & $\mathrm{F}$ & UF & $\mathrm{Jml}$ \\
\hline Dukungan & Kedekatan dengan orang tua & 1,4 , dan 15 & 6 & 8 \\
\hline & Kehangatan dengan orangtua & 3,8 , dan 16 & 17 & \\
\hline Control dari & Pengawasan dari orangtua & 2,20 dan 23 & 18 & 8 \\
\hline & Perintah dari orangtua & 7,13 dan 22 & 11 & \\
\hline $\begin{array}{l}\text { Komunikasi } \\
\text { terbuka } \\
\text { dengan }\end{array}$ & Keterbukaan dengan orangtua & 10,12 dan 19 & 14 & 8 \\
\hline Jumlah & Penanaman nilai-nilai dari orangtua & 5,9 dan 21 & 24 & 24 \\
\hline
\end{tabular}

Pada penelitian ini alat ukur yang digunakan merupakan alat ukur yang dibuat sendiri oleh peneliti dengan mengembangkan teori Hubungan orangtuaanak yang diungkapkan oleh Miller, Benson, dan Galbraith (2001). Terdiri dari 24 item pernyataan yang dapat dilihat pada tabel 1.1 yang merupakan blue print skala Hubungan orangtua-anak.

\section{Teknik Uji Validitas}

Untuk menguji validitas konstruk alat ukur yang digunakan dalam penelitian ini, peneliti menggunakan Confirmatory Factor Analysis (CFA) terdiri dari tiga langkah. Tiga langkah yang dilakukan pada CFA (Umar, 2012) yaitu:

1. Menguji apakah hanya satu faktor saja yang menyebabkan item-item saling berkorelasi (hipotesis uni-dimensional item). Hipotesis ini diuji dengan chi- square. Untuk memutuskan apakah memang tidak ada perbedaan antara matriks korelasi yang diperoleh dari data dengan matriks korelasi yang dihtung menurut teori/model. Jika hasil chi-square tidak signifikan $(\mathrm{p}>0.05)$, maka hipotesis nihil yang menyatakan "tidak ada perbedaan antara matriks korelasi yang diperoleh dari data dan model" tidak ditolak yang artinya item yang diuji mengukur satu faktor saja (uni- dimensional).

Sedangkan, jika nilai chi-square signifikan $(p<0.05)$ maka hipotesis nihil tersebut ditolak yang artinya item-item yang diuiji ternyata mengukur lebih dari satu faktor (multidimensional). Dalam keadaan demikian maka peneliti melakukan modifikasi terhadap model dengan cara memperbolehkan kesalahan pengukuran pada item-item saling berkorelasi tetapi dengan tetap menjaga bahwa item hanya mengukur satu faktor (uni-dimensional). Jika sudah diperoleh model yang fit(tetapi tetap uni-dimensional maka dilakukan langkah selanjutnya.

2. Menganalisis item mana yang menjadi sumber tidak fit, terdapat beberapa hal yang perlu diperhatikan untuk mengetahui item mana yang menjadi sumber tidak fit, yaitu :

a. melakukan uji signifikansi terhadap koefisien muatan faktor dari 
masing-masing item dengan menggunakan t-test, jika nilai $\mathrm{t}$ yang diperoleh pada sebuah item tidak signifikan $(\mathrm{t}<1.96)$ maka item tersebut akan di drop karena dianggap tidak signifikan sumbangannya terhadap pengukuran yang sedang dilakukan.

b. Melihat arah dari koefisien muatan faktor (faktor loading). Jika suatu item memiliki muatan faktor negatif, makan item tersebut di drop karena tidak sesuai dengan pengukuran (berarti semakin tinggi nilai pada item tersebut semakin rendah nilai pada faktor yang diukur).

c. Sebagai kriteria tambahan (optional) dapat dilihat juga banyaknya korelasi parsial antar kesalahan pengukuran, yaitu kesalahan pengukuran pada suatu item yang berkorelasi dengan kesalahan pengukuran pada item lain. Jika pada suatu item terdapat terlalu banyak korelasi seperti ini (misalnyalebih dari tiga), maka item tersebut juga akan di drop. Alasannya adalah karena item yang demikian selain mengukur apa yang ingin di ukur juga mengukur hal lain (multidemensional item).

3. Menghitung faktor skor. Jika langkah langkah di atas telah dilakukan, maka diperoleh item- item yang valid untuk mengukur apa yang ingin di ukur (Umar, 2012).

\section{HASIL PENELITIAN}

\section{Validitas Konstruk Dukungan Orangtua}

Peneliti menguji apakah 8 item yang ada bersifat unidimensional, artinya benar hanya mengukur dukungan orangtua. Dari hasil analisis CFA yang dilakukan, ternyata tidak fit, dengan nilai Chi - Square $=43.35, \mathrm{df}=20, \mathrm{P}$-value $=0.00099$ RMSEA $=0.080$. Oleh sebab itu, peneliti melakukan modifikasi terhadap model, dimana kesalahan pengukuran pada beberapa item dibebaskan berkorelasi satu sama lainnya, hingga diperoleh model fit

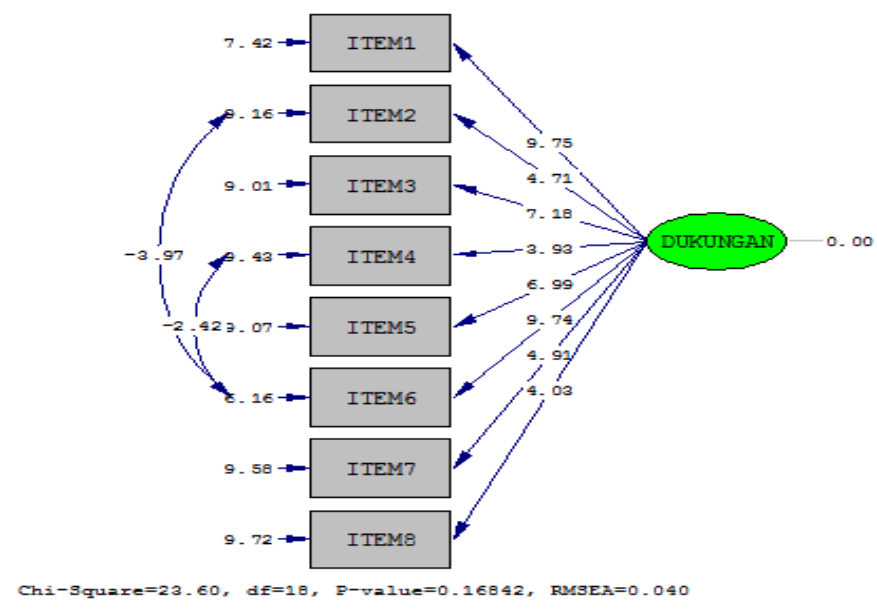

Dapat diketahui bahwa setelah melakukan beberapa modifikasi nilai yang dihasilkan yaitu Chi - Square $=23.60, \mathrm{df}=18 \mathrm{P}$-value $=0.16842$, dan RMSEA $=$ 
0.040, yang artinya model dengan satu faktor (unidimensional) dapat diterima, bahwa seluruh item mengukur satu variabel saja yaitu dukungan orangtua.

Selanjutnya, peneliti melihat apakah signifikan item tersebut mengukur faktor yang hendak diukur, sekaligus menentukan apakah item tersebut perlu di drop atau tidak. Maka dilakukan pengujian hipotesis nihil tentang koefisien muatan faktor dari item. Pengujiannya dilakukan dengan melihat nilai t bagi setiap koefisien muatan faktor, seperti pada tabel 1.2.

Tabel 1.2

Muatan Faktor Item Dukungan Orangtua

\begin{tabular}{lllll}
\hline No & Koefisien & Standar Error & Nilai T & Signifikan \\
\hline 1 & 0.69 & 0.07 & 9.75 & $\sqrt{ }$ \\
2 & 0.39 & 0.08 & 4.71 & $\sqrt{ }$ \\
3 & 0.53 & 0.07 & 7.18 & $\sqrt{ }$ \\
4 & 0.33 & 0.08 & 3.93 & $\sqrt{ }$ \\
5 & 0.51 & 0.07 & 6.99 & $\sqrt{ }$ \\
6 & 0.72 & 0.07 & 9.74 & $\sqrt{ }$ \\
7 & 0.37 & 0.08 & 4.91 & $\sqrt{ }$ \\
8 & 0.31 & 0.08 & 4.03 & $\sqrt{ }$
\end{tabular}

Keterangan : $\operatorname{tanda} \sqrt{ }=$ signifikan $(t>1,96) ; X=$ tidak signifikan

Sebagaimana disebutkan dalam tabel 3.5 dapat dilihat bahwa seluruh item signifikan dan keseluruhan koefisien bermuatan positif. Berdasarkan hasil tersebut, maka semua item dari skala dukungan orangtua dinyatakan signifikan dan tidak ada item yang di drop.

\section{Validitas Konstruk Kontrol Orangtua}

Peneliti menguji apakah 8 item yang ada bersifat unidimensional, artinya benar hanya mengukur kontrol orangtua. Dari hasil analisis CFA yang dilakukan, ternyata tidak fit, dengan Chi-Square $=63.30, \mathrm{df}=20$, Pvalue $=0.00000 \mathrm{RMSEA}=$ 0.104. Oleh sebab itu, peneliti melakukan modifikasi terhadap model, dimana kesalahan pengukuran pada beberapa item dibebaskan berkorelasi satu sama lainnya, hingga diperoleh model fit. 


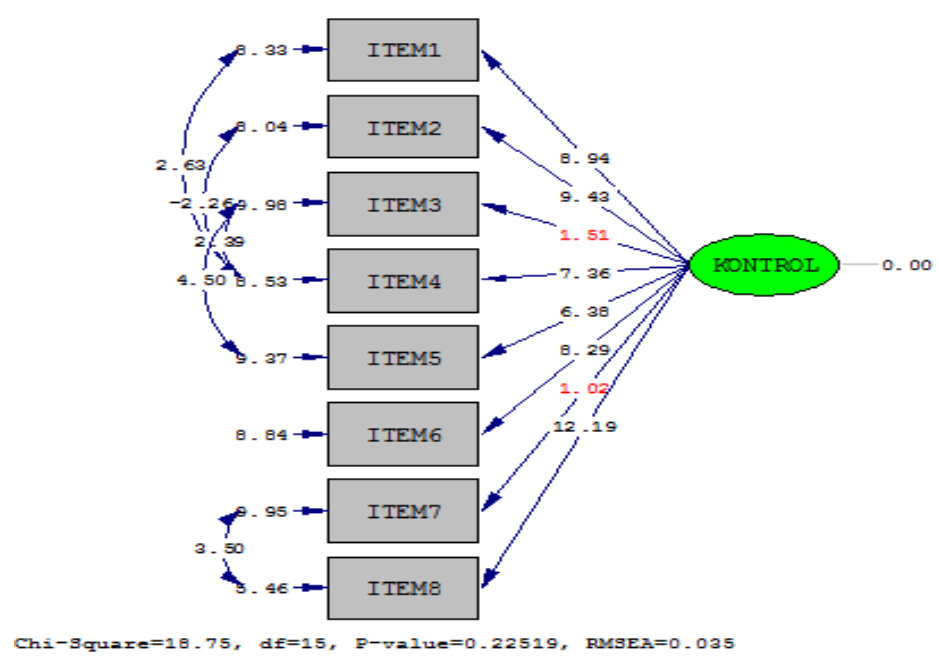

Dapat diketahui bahwa setelah melakukan beberapa modifikasi nilai yang dihasilkan yaitu Chi-Square $=18.75, \quad \mathrm{df}=15, \quad \mathrm{P}$-value $=0.22519$, dan RMSEA $=0.035$, yang artinya model dengan satu faktor (unidimensional) dapat diterima, bahwa seluruh item mengukur satu variabel saja yaitu kontrol orangtua.

Selanjutnya, peneliti melihat apakah signifikan item tersebut mengukur faktor yang hendak diukur, sekaligus menentukan apakah item tersebut perlu di drop atau tidak. Maka dilakukan pengujian hipotesis nihil tentang koefisien muatan faktor dari item. Pengujiannya dilakukan dengan melihat nilai t bagi setiap koefisien muatan faktor, seperti pada tabel 1.3.

Tabel 1.3

Muatan Faktor Item Kontrol Orangtua

\begin{tabular}{lllll}
\hline No & Koefisien & Standar Error & Nilai T & Signifikan \\
\hline 1 & 0.63 & 0.07 & 8.94 & $\sqrt{ }$ \\
2 & 0.66 & 0.07 & 4.71 & $\sqrt{ }$ \\
3 & 0.12 & 0.08 & 1.51 & $X$ \\
4 & 0.56 & 0.08 & 7.36 & $\sqrt{ }$ \\
5 & 0.47 & 0.07 & 6.38 & $\sqrt{ }$ \\
6 & 0.56 & 0.07 & 8.29 & $\sqrt{ }$ \\
7 & 0.08 & 0.08 & 1.02 & $X$ \\
8 & 0.81 & 0.07 & 12.19 & $\sqrt{ }$
\end{tabular}

Keterangan : $\operatorname{tanda} \sqrt{ }=$ signifikan $(t>1,96) ; X=$ tidak signifikan

Sebagaimana disebutkan dalam tabel 1.3 dapat dilihat bahwa terdapat dua item (item no. 3 \& item no. 7) yang tidak signifikan. Kedua item 
dinyatakan tidak signifikan karena memiliki nilai $t<1.96$. sehingga kedua item tersebut harus didrop karena tidak signifikan. Berdasarkan hasil tersebut maka dari skala kotrol orang tua hanya terdapat enam item yang dinyatakan signifikan.

\section{Validitas konstruk komunikasi terbuka orangtua-anak}

Peneliti menguji apakah 8 item yang ada bersifat unidimensional, artinya benar hanya mengukur komunikasi terbuka orangtua-anak. Dari hasil analisis CFA yang dilakukan dengan model satu faktor, ternyata tidak fit dengan ChiSquare $=61.01, \mathrm{df}=20, \mathrm{P}$-value $=0.00000, \mathrm{RMSEA}=0.102$. Oleh sebab itu, peneliti melakukan modifikasi terhadap model, dimana kesalahan pengukuran pada beberapa item dibebaskan berkorelasi satu sama lainnya, maka diperoleh model fit.

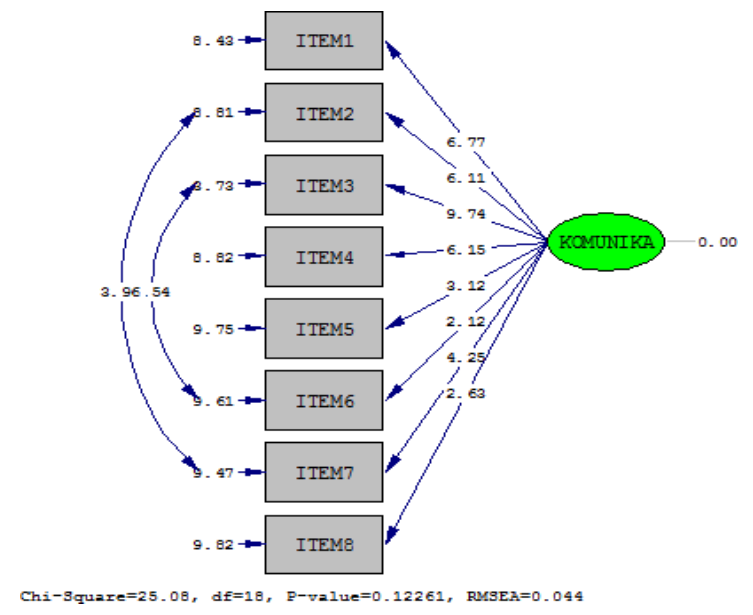

Dapat diketahui bahwa setelah melakukan beberapa modifikasi nilai yang dihasilkan yaitu Chi-Square $=25.08, \mathrm{df}=18 \mathrm{P}$-value $=0.12261$ dan $\mathrm{RMSEA}=$ 0.044, yang artinya model dengan satu faktor (unidimensional) dapat diterima, bahwa seluruh item mengukur satu variabel saja yaitu komunikasi terbuka orangtua-anak.

Selanjutnya, peneliti melihat apakah signifikan item tersebut mengukur faktor yang hendak diukur, sekaligus menentukan apakah item tersebut perlu di drop atau tidak. Maka dilakukan pengujian hipotesis nihil tentang koefisien muatan faktor dari item. Pengujiannya dilakukan dengan melihat nilai t bagi setiap koefisien muatan faktor, seperti pada tabel 1.4.

Sebagaimana disebutkan dalam tabel 1.4 dapat dilihat bahwa seluruh item signifikan dan keseluruhan koefisien bermuatan positif. Berdasarkan hasil tersebut, maka semua item dari skala komunikasi terbuka orangtua dinyatakan signifikan dan tidak ada item yang di drop. 
Tabel 1.4

Muatan Faktor Item Komunikasi terbuka Orangtua-anak

\begin{tabular}{lllll}
\hline No & Koefisien & Standar Error & Nilai T & Signifikan \\
\hline 1 & 0.053 & 0.08 & 6.77 & $\sqrt{ }$ \\
2 & 0.48 & 0.08 & 6.11 & $\sqrt{ }$ \\
3 & 0.80 & 0.08 & 9.74 & $\sqrt{ }$ \\
4 & 0.48 & 0.08 & 6.15 & $\sqrt{ }$ \\
5 & 0.25 & 0.08 & 3.12 & $\sqrt{ }$ \\
6 & 0.20 & 0.10 & 2.12 & $\sqrt{ }$ \\
7 & 0.34 & 0.08 & 4.25 & $\sqrt{ }$ \\
8 & 0.21 & 0.08 & 2.63 & $\sqrt{ }$ \\
\hline
\end{tabular}

Keterangan : tanda $\sqrt{ }=$ signifikan $(t>1,96) ; \mathrm{X}=$ tidak signifikan

\section{KESIMPULAN}

\section{Kesimpulan}

Hasil penelitian menunjukkan bahwa dari 24 item dari skala hubungan orangtua- anak, terdapat dua item yang dinyatakan tidak valid sehingga harus di drop. Disebabkan item tersebut memiliki nilai t- value $<1.96$. Oleh karena itu secara keseluruhan item dalam skala hubungan orangtua-anak yang dibuat sendiri oleh peneliti memiliki validitas yang baik. Artinya, skala hubungan orangtua-anak yang terdiri dari dukungan orangtua terhadap anak, kontrol orangtua, dan komunikasi orangtua dengan anak mengukur satu konstruk yang didefinisikannya, kecuali pada item yang di drop.

\section{DAFTAR PUSTAKA}

Crockett, L J., Raffaelli, M., and Moilanen, K L. (2003). Adolescent sexuality: behavior and meaning. Faculty Publications, Department of Psychology, 245.

Henrich, C., Brookmeyer, K., Shrier, L., \& Shahar, G. (2006). Supportive relationships and sexual risk behavior in adolescence: an ecologicaltransactional approach. Journal of Pediatric Psychology, 31(3), 286-297.

Markham, C., Lormand, D., Gloppen, K., Peskin, M., Flores, B., Low, B., \& House, L. (2010). Connectedness as a predictor of sexual and reproductive health outcomes for youth. Journal of Adolescent Health, 46, S23-S41.

Miller, B C., Benson, B., Galbraith, K A. (2001). Family relationships and adolescent pregnancy risk: a research synthesis. Journal of Developmental Review, 21, 1-38

Parkes, A., Henderson, M., Wight. D., \& Nixon, C. (2011). Is parenting associated with teenagers' early sexual risk-taking, autonomy and relationship with sexual partner?. Journal of perspectives on sexual and reproduction health, 43(1), 30- 40 . 
Scony, M.E., Deptula, Dp., \& Henry, D.B. (2010). How can parents make a deferrence? Longitudinal association with adolescent sexual behavior. Journal of family psychology, 24(6), 731-739.

Sidze, E., \& Defo, B. (2013). Effects of parenting practices on sexual risk-taking among young people in Cameroon. BioMed Central.

Steinberg, L., Silk, J S. (2002). Handbook of parenting: parenting adolescents. New Jersey: Lawrence Erlbaum Associates, Inc.

Umar, J. (2012). Jurnal Pengukuran Psikologi dan Pendidikan Indonesia, 2(2), 115116 